\title{
Cloning and gene expression equine leukocyte $\alpha$-interferon in cells of Escherichia Coli
}

\author{
A. A. Muttar M.I. Potapovich V.A. Prokulevich \\ Belarus state university - microbiology
}

\begin{abstract}
Interferon'splays role in innate immune responses through upregulation of costimulatory molecules and induction of proinflammatory cytokines.interferons including interferon alpha (IFNA). The present study characterized IFNA cDNA and predicted protein. The interferon's play a great role in protection from infections, which have been called by microorganisms, and also have powerful antiproliferation and immunomodulation activity. The purposes of study:cloning andexpression of horse leukocyte interferonand purification the product protein. The results and discussion : In the result we isolated (DNA) from equine leukocyte in blood, which was using in the quality of matrix for amplification of $\alpha$-interferon gene with PCR HELP, and isolation gene $\alpha$-interferon and transformation in vector puc18 and expression vector PET24b (+) and recombinant plasmid was transformed into E. coli strain BL21( codon plus 440) induction with IPTG.The results showed the protein having the same molecular weight as horse interferon alphaabout $18.5 \mathrm{kDa}$.
\end{abstract}

\section{Introduction}

In interferon (IFNs) were discovered in 1957 as a biological agent intervention in viral replication. They are mixtures of the secrets of proteins occurring in vertebrates and can be classified as cytokines. Interferon's are multifunctional components of defense against viral and parasitic infections and certain tumors. They affect the immune system function in various forms, interferon's perform various activities, primarily synthesize many proteins.Interferon's are useful in the case of many human diseases: in leukemia, Kaposi's sarcoma, myelogenous leukemia, practically, lymphoma, chronic illness and chronic infection, hepatitis $\mathrm{B}$ and $\mathrm{C}$ viruses.Interferon's are a class of glycoproteins that have antiviral,

\section{The Material and Methods}

A. Bacterial strains and plasmids:

The bacteria strain E. coli XL-1 Blue (F 'proAB lacIqlacZ $\Delta$ M15 Tn10 (Tcr) / recA1 endA1 gyrA96 (Nalr) thi-1 hsdR17supE44 relA1 lac) from the collection of the Department of Molecular Biology, Faculty antiproliferative and immunoregulatory activity( Wang $\mathrm{H}$, Zhou M). There is three major types of interferon's: I and II and IIIinterferon's.Type I form a large group of proteins that includes IFN alpha, delta, beta, kappa, omega, etc.Type II has IFN din immune interferon, which has the interferon's and most mammals, is encoded by a single gene.Type II has IFN lambda (Kotenko, S. V.).The horse (EquusCaballus) found at least 6 genes encoding interferon alpha that is collected on chromosome 23.The aim of this study:cloning and subsequent gene expression equine $\alpha$ interferon in the bacteria $E$. coli to obtain purified equine $\alpha$-interferon may become the basis for the establishment of appropriate therapeutic and preventive veterinary drugs.

of Biology, Belarusian State University was used for cloning recombination plasmids.(Studier F. W., Rosenberg)The cells of $E$. coli BL21 ( $\lambda \mathrm{DE} 3)$ (hsd, gal, $\lambda$ cIts857, ind1, Sam7, nin5, lacUV5T7gen1), lysogenic for bacteriophage $\lambda \mathrm{DE} 3$, 
containing the gene of bacteriophage $\mathrm{T} 7$ RNA polymerase under the control of PlacUV5-promoter in the cells of strain E. coli BL21-CodonPlus (DE3)-RIPL, containing amplified copies of the gene-Data is rarely encountered in prokaryotic m-RNA was performed inducible expression of target gene transcription in the bacteriophage T7.Plasmid pUC18 was used as a vector for the cloning of the gene sequence of horse $\alpha$ inte-rferon.Plasmid pET24b (+) was used as an expression vector.(Studier F., Moffatt B.

A.)

B. Genetic-engineering techniques and enzymes:

Total DNA was isolated according to Construction(Mathew), isolation, restriction analysis of recombinant plasmid carrying ca +2 dependent transformation and
DNA electrophoresis was performed in under with generally accepted experimentprotocol. We used enzymes and buffer system firm MBI fermentas (Lithuania).polymerasechain reaction (PCR) (Frank C.)was performed in a mixture of standard composition with used programmable thermostat: Veriti (96well thermal cycle).Primers for PCR were designed on the basis of information from a database of nucleotide sequences of GeneBank. Sequencing was performed by the method of Sanger on the sequencer ALFExpress.Electrophoresis analysis of bacterial proteins was performed in $12 \%$ polyacrylamide gel under denaturing conditions with $0,1 \%$ SDS by the method. The gel was stained in a solution of Coomassie blue R-250.

\section{Results and discussion}

Geneamplification equine leukocyte $\alpha$ interferon with helps PCR used total DNA isolated from horse blood. At database GeneBank nucleotide sequences (codes M14540, M14541, M14542, M14543) primers were designed:

F1 (5-GGC CATATG TGT GAC CTG CCT CAC ACC CAT AGC CTG GGC-3 Select a

site for restriction endonuclease $N d e 1$ ) and R1 (5-gcg GAATTC GAT AAGCTT ACT CTG CTG CAA GTT TGT GGA TGA AGA GAA -3 allocated sites for restriction enzymes Eco R1 and HindIII) product size amplification equine interferon gene is (483) bp that is fully consistent with the expected (figure 1).

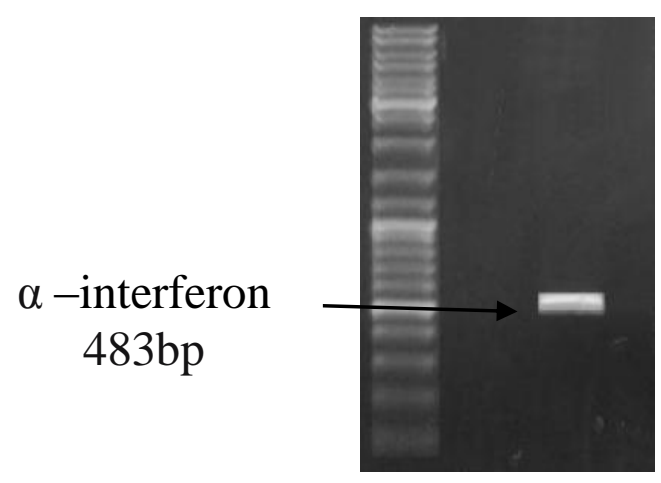

Figure 1. Gene equine leukocyte $\alpha$-interferon

The amplification product is embedded into a plasmid PUC18 of restriction sites for Nde I and Eco RI,(neb.com/restriction_enzymes)then spent his sequencing, which showed that the nucleotide sequence of the amplified fragment is equal to a full sequence of the gene equine leukocyte $\alpha$-interferon in the database.Amplification product by restriction endonuclease sites $\mathrm{Nde}$ I and Eco RI embedded into plasmid pUC18.Takoe inlining prevents gene expression and protein formation, which according to the literature can (Sambrook) to degrade bacterial intracellular proteases $\mathrm{E}$. coli, or have lethal effect on cells of the new owner. Hybrid DNA transformed cells E. coli XL Blue. Selection of clones carrying the 
plasmid gene equine interferon produced on the selective medium EMB. The presence of inserts equine interferon gene in the plasmid pUC18 tested PCR analysis using primers
F1 and R1, complementary to the 5'-and Z'terminal sequences of equine interferon gene (Fig. 1), and restriction analysis (Fig. 3).

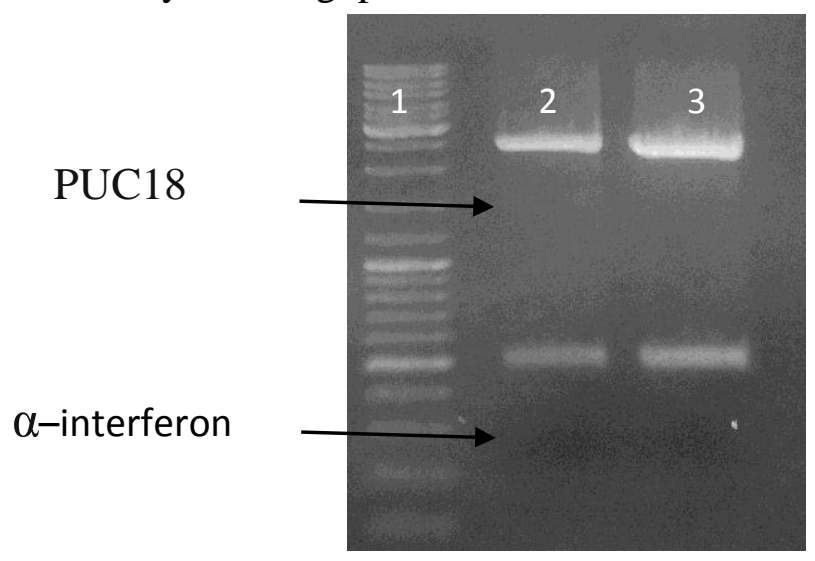

Figure 3.Electrophoresis results restriction Analysis Note: Track 1 - molecular weight marker Fermentas SM0333, lanes 2,3- plasmid pUC18, processed restriction enzymes Nde I and EcoR I.

The amplification product is embedded into a plasmid PUC18 the sites for the restriction Nde I and EcoR I. then spent his sequencing, which showed that the nucleotide sequence of the amplified fragment is equal to a full sequence of the gene equine leukocyte $\alpha$-interferon in the database.In the next stage of the gene equine leukocyte $\alpha$-interferontransferred into an expression vector $\mathrm{pET} 24 \mathrm{~b}(+)$ for restriction endonuclease sites Nde I-Eco RI. The resulting recombinant plasmids, named respectively M14541, (Figure 4)

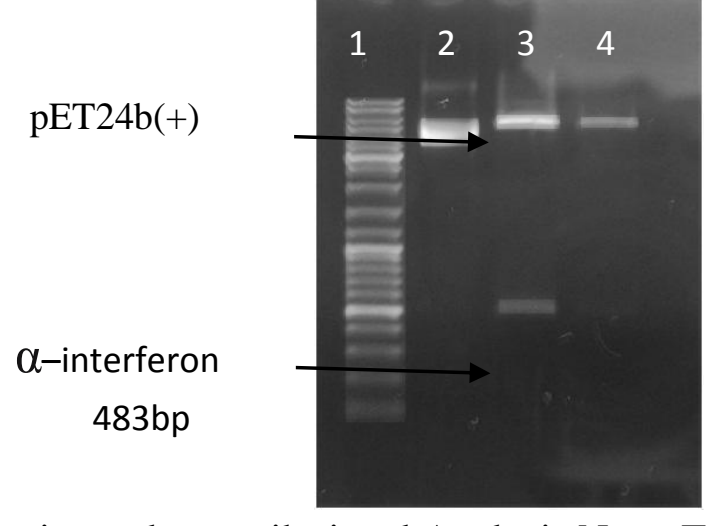

Figure 4.Electrophoresis results restrik-tional Analysis Note: Track 1 - molecular weight marker Fermentas SM0333, lanes 2, plasmid pET24b (+), 3 - plasmid pET24b (+), processed restriction enzymes Nde I and EcoR I, .4-carved pET24b (+).

Transformed strain of E. coliBL21 condon plus 440 (Jerpseth), which is lysogenic for bacteriophage $\lambda \mathrm{DE} 3$, containing the gene of the RNA polymerase of bacteriophage $\mathrm{T} 7$ under the control of PlacUV5-promoter. E. coli cells VL21 codon plus 440, inherit these plasmids were grown in the presence of IPTG (isopropyl- $\beta$ D-tiogalaktopiranozid) for induction of gene expression in equine leukocyte $\alpha$-interferon (Fig. 5). 


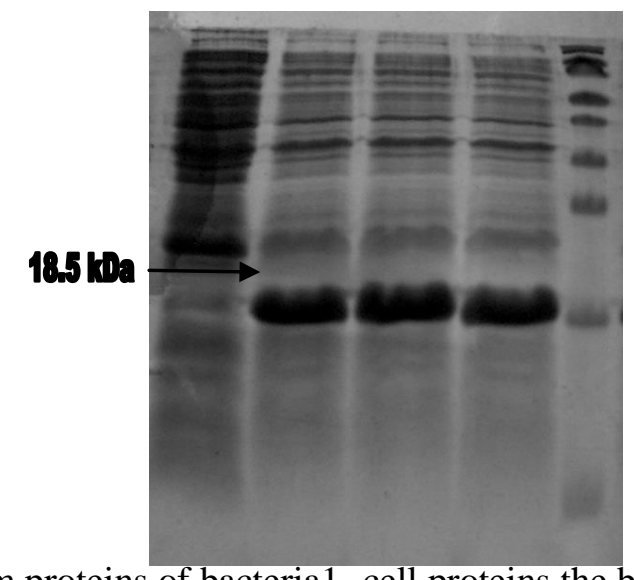

Fig.5.SDS-electrophoregram proteins of bacteria1- cell proteins the bacteria $E$. coli BL21 condon plus 440 + pet $24 \mathrm{~b}+$ without IPTG.2,3,4 different proteins the bacteria E. coli BL21 condon plus $440+$ pet $24 \mathrm{~b}+4$ hours after induction of IPTG at a co-ncentration of $1.0 \mathrm{mg} / \mathrm{dL} .5$ - proteins of molecular weight standards (from top to bottom - $170 \mathrm{kDa}, 130 \mathrm{kDa}, 95 \mathrm{kDa}, 72 \mathrm{kDa}, 55 \mathrm{kDa}, 43 \mathrm{kDa}, 26 \mathrm{kDa}, 10 \mathrm{kDa}$ ) (Fermentas SM0671).

These results indicate that after the induction of IPTG in bacterial cells (Frank C.), containing the recombinant plasmid with the gene of equine leukocyte $\alpha$ interferon, there is accumulation of the protein corresponding to the molecular weight of horse $\alpha$-interferon (about $18.5 \mathrm{kDa}$ ).

\section{References}

1- Alan S. Gerstein, molecular biology problem solver a laboratory guide Edition. 2001,p180-185 new York.

2- Frank C. Hay Olwyn M.R. Westwood Practical Immunology,Fourth Edition 2002 p157-160 londonuk.

3- Jerpseth, B., Callahan, M. and Greener, A. (1997) Strategies 10(2):37-38.

4- Kotenko, S. V., G. Gallagher, V. V. Baurin, A. Lewis-Antes, M. Shen, N. K. Shah, J. A. Langer, F. Sheikh, H. Dickensheets, and R. P. Donnelly. 2003. IFN- $\lambda$ s mediate antiviral protection through a distinct class II cytokine receptor complex. Nat. Immunol. 4:69-77.

5- Mathew C.G.P. //Walker Ed., John M. Methods in molecular biology.Nucleic acids. Humana Press, 1984. Chapter 5. P. 32-34.

6- Sambrook, J., Fritsch, E.F. \&Maniatis, T. Molecular cloning. A laboratory
On these results we can conclude:

- Using the designed specific primers amplification gene and the equine leukocyte $\alpha$-interferon.

- Amplification product of the sequenced and cloned into the expression vector.

- Protein produced by size-fits to equine leukocyte $\alpha$-interferon(about $18.5 \mathrm{kDa}$ ).

manual, $2^{\text {nd }}$ Edition. 1998 Cold Spring Harbor.

7- Steffen. C. (Ed). PCR Applications Manual, 2nd edition. 1999 Roche.

8- Studier F. W., Moffatt B. A. // J. Mol. Biol. 1986. Vol. 189. P. 113-130.

9- Studier F. W., Rosenberg A. H., Dunn J. J., Dubendorff J. W. // Meth. Enzymol. 1990. Vol. 185. P. 60-89.

10- Wang H, Zhou M, Brand J, Huang L. (2007). "Inflammation Activates the Interferon Signaling Pathways in Taste Bud Cells". Neurosci 27 (40): 10703-10713.

11- http://www.neb.com/nebecomm/tech_ref erence/restriction_enzymes/double_ digests.asp

12- http://www.ncbi.nlm.nih.gov/genbank/G enbankOverview.htmlDiagnostics Gmb H, Mannheim, Germany. 
AL-Qadisiya Journal of Vet.Med.Sci. $\quad$ Vol./12 No./1 2013

\section{استنساخ تعبير جين الانترفيرون الفا من كريات الدم البيضاء للحصان في بكتريا Escherichia Coli القولون الانون}

$$
\begin{aligned}
& \text { عرفات عبد الرزاق مطر مامعة بيلاروس الحكومية ـ الأحياء المجهرية ملاديمير بروكليفيج } \\
& \text { الخلاصة }
\end{aligned}
$$

الانترفيرونات تلعب دورا في الاستجابة المناعية الفطرية من خلال اعادة التنظيم وتحفيز السايتوكاينيز من خلال

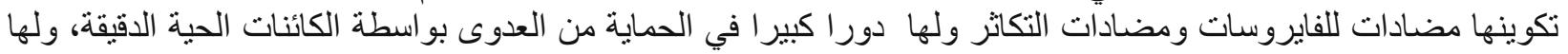

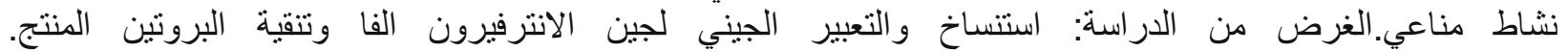

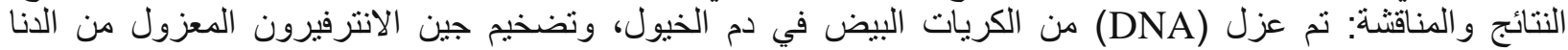

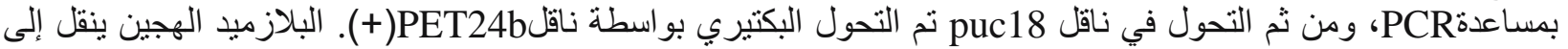

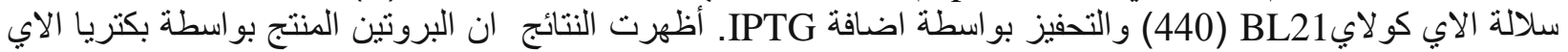

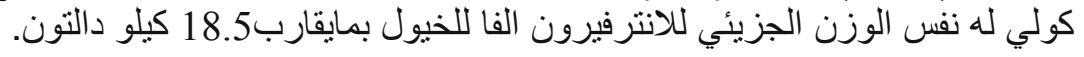

